\title{
Correlation between paleosol-soil magnetic signal and climate
}

\author{
M. J. Orgeira ${ }^{1,2}$ and R. H. Compagnucci ${ }^{1,3}$ \\ ${ }^{1}$ Consejo Nacional de Investigaciones Científicas y Técnicas, CONICET, Argentina \\ ${ }^{2}$ Departamento de Ciencias Geológicas, FCEN, Universidad de Buenos Aires, Argentina \\ ${ }^{3}$ Departamento de Ciencias de la Atmósfera, FCEN, Universidad de Buenos Aires, Argentina
}

(Received December 18, 2005; Revised June 4, 2006; Accepted June 6, 2006; Online published November 8, 2006)

\begin{abstract}
A comparison of the index of potential water storage (PWS) with the magnetic properties of soils in Russia and of Argentina and China paleosols suggests the existence of one or two climatic thresholds that affect the formation, preservation or depletion of ferrimagnetic minerals. Soils characterized by a positive PWS are wetted during an important part of the year, creating an appropriate environment that favors the depletion of ferrimagnetic minerals due to mainly reductive dissolution. Such soils are characterized by a depletion of detrital ferrimagnetic minerals, as observed in Argentinean soils and paleosols. On the other hand, a negative PWS prevents highly reducing conditions in the soil, and the detrital ferrimagnetic minerals are preserved. The environmental conditions of these soils allow the formation of (superparamagnetic) pedogenic minerals, together with the preservation of lithogenic minerals. These conditions produce a net magnetic enhancement of the soil, as observed in Russia and China. The second threshold in PWS could be at a positive value. Above this second threshold, the water content of the soil during practically the whole year could allow the formation of (superparamagnetic) pedogenic minerals. This threshold could explain differences in the magnetic enhancement or depletion of Argentina soils characterized by a positive PWS.
\end{abstract}

Key words: Environmental magnetism, paleoclimate, Late Cenozoic, loess and paleosol sequences.

\section{Introduction}

The magnetic properties of sedimentary sequences, such as loess/paleosol deposits, are strongly influenced by changes in the concentration of ferrimagnetic iron oxides, such as magnetite or titanomagnetite. Recent studies have suggested that the magnetic properties of different loesspaleosols sequences reflect past climate oscillations (e.g. Liu et al., 1992; Banerjee and Hunt, 1993; Maher, 1998; Fang et al., 1999; Maher and Thompson, 1999; Liu et al., 2004). Consequently, magnetic measurements have been used as a quantitative proxy for reconstructing paleoprecipitations (Maher and Thompson, 1994; Liu et al., 1995). However, at least one study reported relevant inconsistencies in the establishment of this type of correlations (Bloemendal and Liu, 2005).

The in-situ authigenesis of magnetic minerals during soil formation was initially reported for a range of modern soils in the humid temperate zone (Mullins, 1977; Maher, 1986; Maher and Thompson, 1988). It was soon recognized that the higher values of magnetic susceptibility and other magnetic parameters of Chinese paleosols with respect to unweathered loess (magnetic enhancement) is caused by ultrafine $(<0.5 \mu \mathrm{m})$ ferrimagnetic grains (Zhou et al., 1990; Maher and Taylor, 1988; Heller et al., 1991). While the exact mechanism by which these particles are formed is still under debate, the presence of ferrimagnetic pedogenic minerals and their dependence on the climate is widely recog-

Copyright (c) The Society of Geomagnetism and Earth, Planetary and Space Sciences (SGEPSS); The Seismological Society of Japan; The Volcanological Society of Japan; The Geodetic Society of Japan; The Japanese Society for Planetary Sciences; TERRAPUB. nized (Maher and Thompson, 1999), and various correlations between the magnetic enhancement in modern soils and rainfall have been suggested (Heller et al., 1993; Maher and Thompson, 1994, 1995; Han et al., 1996; Maher et al., 2003).

Bloemendal and Liu (2005), on the other hand, reported a rock magnetic and geochemistry study of two PlioPleistocene Chinese loess and paleosol sequences (Duanjiapo and Luochuan localities) that demonstrates important discrepancies between magnetic and geochemical indicators of weathering and soil forming intensity. They concluded that any attempt to predict paleoprecipitation using magnetic data could lead to the wrong conclusions.

Unlike the Chinese Loess Plateau, South American loess/paleosols sequences are not characterized by a systematic magnetic enhancement of the paleosols. Previous studies (Orgeira et al., 1998, 2003, among others) have shown that Pampean plain paleosols are not magnetically enhanced with respect to the substrate. Within this framework, the study of South American loess/paleosols sequences is relevant for two reasons. First, a comparison of these sequences with others sites provides a stringent constraint for models attempting to explain pedogenetic mechanisms that involve ferrimagnetic minerals. Second, South American loess/paleosols sequences are of particular interest for a world Paleoclimatic reconstruction.

In this article we suggest a possible model for the magnetic properties of South American loess/paleosols sequences. Acording to this model, the detrital ferrimagnetic minerals, mainly of volcanic origin, are chemically altered and subsequently dissolved in the soils. The iron 
Table 1. Results of environmental magnetism studies of loess and loessic sediments-paleosols sequences from Pampean plain (Argentina). The dry period is determinate in relation with present climatic condition of Pampean area.

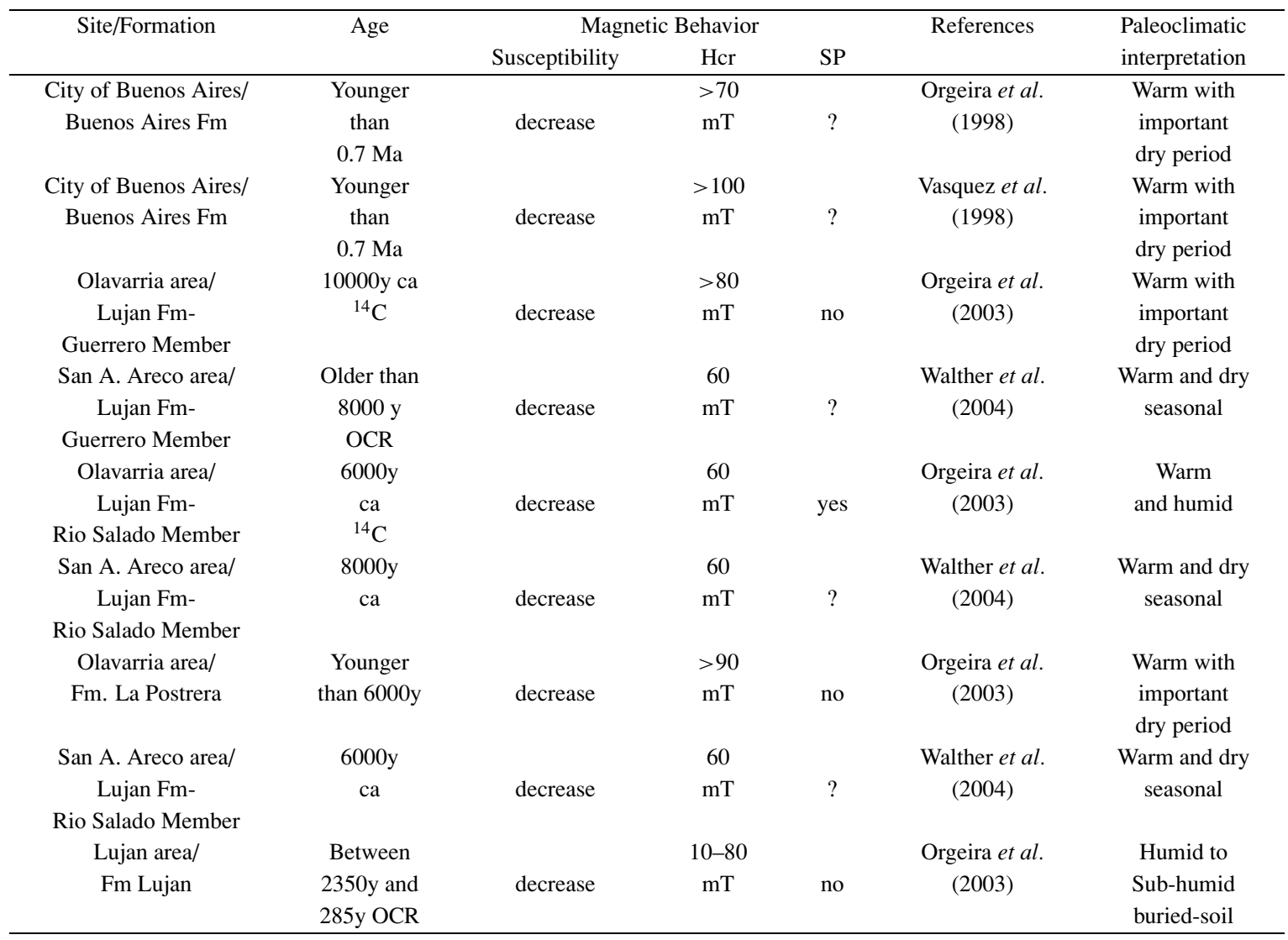

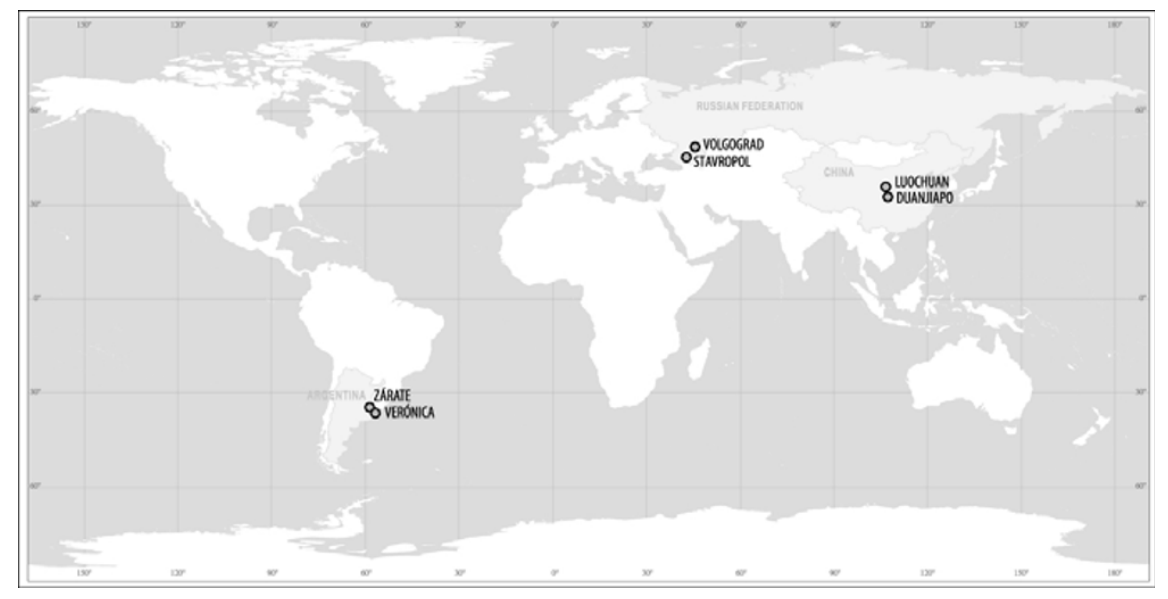

Fig. 1. Location map of the analyzed sites.

released during the alteration of detrital minerals is then chemically re-precipitated to form pedogenic ferrimagntic and antiferromagnetic minerals. The removal of large (titano)magnetite particles and the subsequent precipitation of ferrimagnetic nanoparticles seem to be contradictory at first glance because dissolution processes are expected to preferentially remove the smaller particles. However, depletion and authigenesis could act as competing porcesses characterized by seasonal variations: one process is then favored over the other, depending on the fluctuation in environment conditions, giving either a net increase or decrease of the bulk magnetic signal.

We also compare a modified version of the pedogenic model proposed by Orgeira et al. (2006) with climatic and magnetic parameters of selected sites in China, Russia and Argentina (Bloemendal and Liu, 2005; Maher et al., 2003; Orgeira et al., 2006). The sites chosen (Fig. 1) represent a variety of climates (from warm humid to continental semiarid) with different magnetic responses (i.e. magnetic enhancement or depletion). 


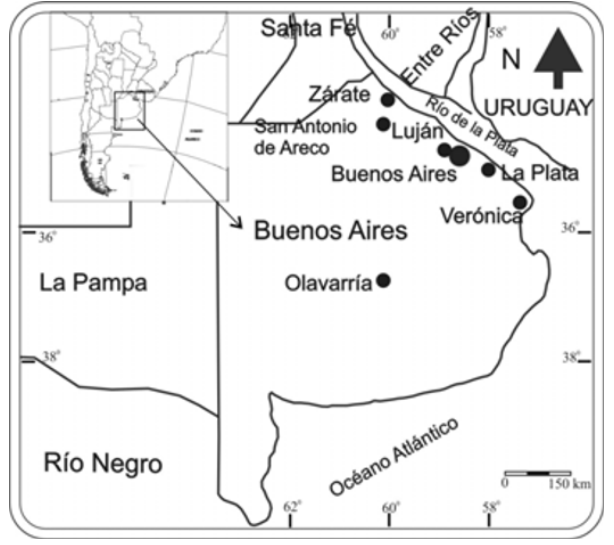

Fig. 2. Location map of Pampean studied sites (Argentina).

\section{Report on Studies in the Pampean Area (Ar- gentina)}

Table 1 summarizes the results of magnetic measurements of loess and loessic sediments-paleosol sequences from Pampean plain (Argentina) (Fig. 2). Unlike in China, the paleosols are not characterized by a systematic magnetic enhancement. The magnetic mineralogy of Pampean Plain loesses reflects its volcanic origin, marked by the abundance of volcanic glass (Frenguelli, 1955, 1957). The magnetic signature of these loesses is dominated by low-Ti titanomagnetites. In many cases, the Pampean volcanic glass shows little evidence of alteration, although the concentration of trace elements present in the glass, such as As, in shallow groundwaters suggests at least a partial alteration of the volcanic Pampean glass (Nicolli et al., 2004).

The loess outcrops reported in Table 1 have been assigned to the "Pampeano" (according to Ameghino, 1889, 1908; Frenguelli, 1950) and are formally called the Buenos Aires Formation (late Pleistocene) and La Postrera Formation (Holocene). The loessic sediments on top have been assigned to the "Post pampeano" (sensu Frenguelli 1950) and are formally assigned to the Lujan Formation (PleistoceneHolocene) (Fidalgo et al., 1991; Fidalgo, 1992).

A brief review of the geologic antecedents of Pampean loess can be useful for the better understanding of the reader. Sudamerican loess is generally known as the Pampeano unit. Ameghino (1889) used the name Bonaerense as a synonym for the upper section of his Pampean Formation, however, Parodi and Parodi (1952) formally named this unit the Buenos Aires Formation, which was originally assigned by Frenguelli (1957) to the Bonaerense. He described the Bonaerense as a thick homogeneous unstratified loess unit, fined grained, light reddish brown, with a homogeneous distribution of calcareous nodules. Various loess layers and paleosols are interbedded within this unit. A Lujanense land mammal age, tentatively assigned to upper Pleistocene, was proposed by Pascual et al. (1965) on the basis of mammalian fossils found within the unit. Claperton (1993) summarized most of the existing information of the Pampeano loess Formation (formally named by Teruggi, 1957), within which the Bonaerense would be the upper section. Ameghino (1889) used the term Lujanense for the upper sediments (Post-Pampeano deposits) of what he called the Pampean
Formation. Frenguelli $(1928,1950,1957)$ described this unit in further detail and placed it in the upper limit of the Pleistocene.

The sediments that form the infill in Pampean valleys are overlain by the Platense, a term that describes the gray marls of Lujan. Frenguelli (1945) provides an extended and detailed description of the Platense. Fluvial and lacustrine sediments known as 'Lujanense' and 'Platense' have been identified by Fidalgo et al. (1975) as the Lujan Formation, which contains the Guerrero Member (Lujanense) and the Rio Salado member (Platense). Two buried soils, Puesto Callejon Viejo (SPCV; between the members) and Puesto Berrondo Soils (SPB; over Rio Salado) were also described (Fidalgo et al., 1975; Fidalgo, 1992). Finally, Frenguelli (1950) called the loessic sediments Cordobense or Aeolian Platense. At the present time, they are known as the La Postrera Formation (Fidalgo et al., 1975).

The main objective for taking care in selecting the Argentinian units to be studied was to cover the widest possible temporal interval. Pure loess deposition was interrupted at the end of the Pleistocene, giving place to the deposition of reworked loess (Formation Lujan), mainly as a result of fluvial action. During a brief term in the Holocene the deposition of pure loess conditions restarted, and it is represented by the La Postrera Formation. The sedimentologic and mineralogical characteristics of the "Pampeano" (loess) and the "Post-pampeano" (loessic silts) are similar (Frenguelli, 1955 and later contributions). This allows a direct comparison of the magnetic properties of the paleosols in both lithologic units on the basis of substantially identical parental substrates.

Orgeira et al. (2006) studied the current soils of the Pampean Plain collected from Argiudolls profiles located in the Zárate and Verónica sites (Fig. 2). Such soils have developed from loess of the Buenos Aires Formation. Soils from Zárate are magnetically enhanced, whereas a decrease in the magnetic signal has been observed in soils from Veronica. Measurements of the $\mathrm{pH}$ of these soils showed neutral to basic environmental conditions in the $\mathrm{B}$ and $\mathrm{BC}$ horizons (from 7.1 to 8.8 inches at Verónica; from 7.46 to 9.2 inches at Zárate; Orgeira et al., 2006).

A comparative analysis of the magnetic results and the climatic tables at each location suggested that the accumulation of pedogenic SP minerals in Zárate could be due to the difference between PP (precipitation) and PET (potential evotranspiration), which remains positive during a longer period of the year (Orgeira et al., 2006). On the other hand, the decrease in the concentration of magnetic minerals in Veronica has been interpreted as arising from the dissolution of detrital titanomagnetite.

\section{Hypothesis on the Origin of the Magnetic Signal in the Pampean Region}

While climate is supposedly one of the main factors that controls pedogenic processes involving magnetic minerals, other factors, such as soil microclimate, clay content and drainage have to be taken into account (Orgeira et al., 2004, 2006). Evans and Heller (2003) proposed a sequence for the formation of secondary ferromagnetic minerals that takes into account partial dehydration and oxidation of ferrihy- 


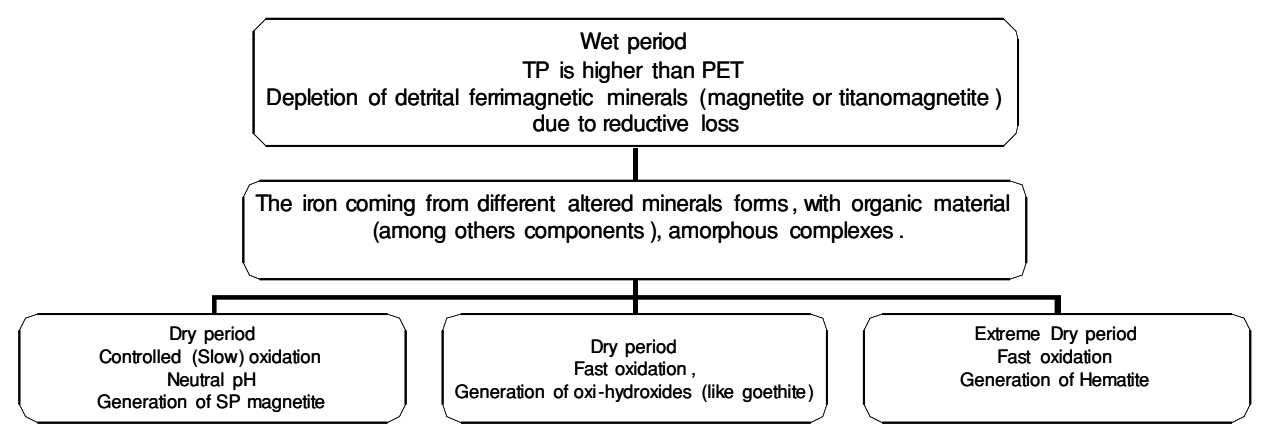

Fig. 3. Schematic hypothesis for the origin of the Pampean magnetic signal.

drite. However, this model cannot explain the lack of magnetic enhancement in Argentinian soils.

Our hypothesis to explain the magnetic properties of soils and paleosols in the Pampean region is based on two processes. The first process is a chemical loss of detrital ferrimagnetic minerals in the $\mathrm{B}$ horizon due to a combination of factors occurring during a period of water storage in the soil. During the disolution process, $\mathrm{Fe}^{2+}$ and $\mathrm{Fe}^{3+}$ ions are released. The low solubility of the latter leads to the precipitation of weakly magnetic Fe(III) minerals, such as goethite or hematite, while the soluble $\mathrm{Fe}^{2+}$ ions can be transported by circulating water to other sites where precipitation of SP magnetite or reoxidation may occur. The dissoltution of titanomagnetites must be compatible with the chemical conditions found in modern soils from the investigated sites in Argentina, i.e. slightly acidic to neutral $\mathrm{pH}$ and moderately reducing Eh. Under these conditions, a rapid dissolution of magnetite is not expected. However, the following additional factors could favor the dissolution process.

1) Rain water that infiltrates the soil can transport organic ligands produced by the decomposition of organic matter. Appelo and Postma (1993) showed that organic ligands have a strong affinity to $\mathrm{Fe}$, considerably promoting the dissolution of Fe(III) minerals. According to these authors, the presence of ligands is more important than $\mathrm{pH}$ in promoting dissolution by absorbing onto the surface of detrital particles to form an inner sphere complex (Stumm, 1992). Bicarboxilic acids are the most effective in forming complexes; see, for example, the following with oxalic acid:

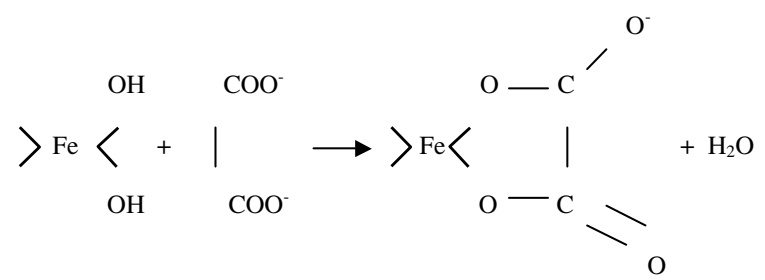

Furthermore, organic ligands tend to stabilize $\mathrm{Fe}^{2+}$ ions, thereby preventing their oxidation to $\mathrm{Fe}^{3+}$. The net effect is that the reducing power of $\mathrm{Fe}(\mathrm{II})$ is greater when it is associated with a ligand than when it is free in solution.

2) Even though water that infiltrates from the surface contains dissolved $\mathrm{O}_{2}$, the latter is quickly lost in the first centimeters of the soil (A horizon) during the degradation of organic matter. This is particularly true in recharge areas with silty soils — such as the Pampean region-where shallow groundwater does not contain detectable levels of dissolved $\mathrm{O}_{2}$ (Frezze and Cherry, 1979). As a consequence of this, a moderately reducing environment can be expected in the $\mathrm{B}$ and $\mathrm{B} / \mathrm{C}$ horizons. This redox gradient shifts the stability range of iron minerals, favoring their precipitation or dissolution.

3) Vertical oscillations of the water table in Argentinian soils can be inferred from the occurrence of specific markers, such as the presence of calcareous concretions. A vertical movement of the water table produces a shift in the redox gradient that is accompained by a change in the chemical stability of $\mathrm{Fe}^{2+}, \mathrm{Fe}^{3+}$ and iron minerals. When the water table drops during periods of intense evapotranspiration, (summer season), the system becomes more oxidant near the surface, leading to the precipitation of $\mathrm{Fe}(\mathrm{III}) \mathrm{min}$ erals; in addition, the transport of organic ligands in the $\mathrm{B}$ horizon is inhibited by the drier conditions. The opposite is true in winter, when the water table rises and approaches the surface, thereby promoting a reducing environment with a slightly more acid rainwater recharge. The presence of organic ligands under reducing conditions in the $\mathrm{B}$ and $\mathrm{B} / \mathrm{C}$ horizons can promote the reductive dissolution of detrital titanomagnetites (MacBride, 1994).

Another plausible dissolution mechanism for the detrital (titano)magnetite was proposed by Florindo et al. (2003) to explain magnetite depletion in siliceous marine sediments. These researchers suggested that elevated silica pore-water concentrations arising from the diagenesis of silicic volcanic ash favor the transformation of magnetite into smectite under conditions that are not obviously related to the redox state of the environment. The reactive nature of the volcanic glass fragments abundant in Pampean loess sediments could produce high-resolution silica pore-water concentrations that promote the dissolution of detrital ferrimagnetic minerals. Figure 3 provides a hypothesized scheme for the origin of the Pampean magnetic signal.

\section{Climatic Analysis \\ 4.1 Methodology}

Orgeira et al. (2006) discussed the relationship between the magnetic signal and the climate for present soils from Buenos Aires province. They used monthly data of PET and total precipitation (TP) as a proxy for influence of climate on the magnetic properties of the soils.

The PET is an estimate of the loss of water from the earth 
Table 2. Climatological data of the analized sites of Argentina, China and Russia.

\begin{tabular}{|c|c|c|c|c|c|c|c|}
\hline $\begin{array}{l}\text { Magnetic } \\
\text { data site }\end{array}$ & $\begin{array}{l}\text { Meteorological } \\
\text { station site } \\
\text { Distance from the } \\
\text { magnetic data site }\end{array}$ & Lat.Long & $\begin{array}{l}\text { Altitude } \\
(\mathrm{m})\end{array}$ & $\begin{array}{l}\text { Annual TP } \\
(\mathrm{mm})\end{array}$ & $\begin{array}{l}\text { Annual mean } \\
\text { Temp. }{ }^{\circ} \mathrm{C}\end{array}$ & $\begin{array}{c}\text { Annual PETc } \\
(\mathrm{mm})\end{array}$ & $\begin{array}{l}\text { PWS } \\
(\mathrm{mm})\end{array}$ \\
\hline Zárate & $\begin{array}{c}\text { San Pedro } \\
\text { Less than } 30 \mathrm{~km}\end{array}$ & $\begin{array}{c}33.68^{\circ} \mathrm{S} \\
59.68^{\circ} \mathrm{W}\end{array}$ & 28 & $1,115.00$ & 16.7 & 823.98 & 291.01 \\
\hline Verónica & $\begin{array}{c}\text { Punta Indio } \\
\text { Less than } 20 \mathrm{~km}\end{array}$ & $\begin{array}{l}35.36^{\circ} \mathrm{S} \\
57.28^{\circ} \mathrm{W}\end{array}$ & 22 & 885.00 & 15.9 & 809.02 & 75.98 \\
\hline Luchuan & $\begin{array}{c}\text { Qingyan } \\
\text { Xifengzhen } \\
\text { Less than } 20 \mathrm{~km} \text {, } \\
\text { similar altitude }\end{array}$ & $\begin{array}{c}35.73^{\circ} \mathrm{S} \\
107.63^{\circ} \mathrm{E}\end{array}$ & 1,423 & 544.87 & 8.3 & 603.9 & -59.03 \\
\hline Dujuanjiapo & $\begin{array}{c}\text { Xian } \\
\text { Less than } 50 \mathrm{~km} \text {, } \\
\text { similar altitude }\end{array}$ & $\begin{array}{c}34.3^{\circ} \mathrm{N} \\
108.93^{\circ} \mathrm{E}\end{array}$ & 398 & 532.15 & 13.4 & 795.71 & -263.56 \\
\hline Stavropol & Stavropol & $\begin{array}{c}45.2^{\circ} \mathrm{N} \\
42^{\circ} \mathrm{E}\end{array}$ & 511 & 571.00 & 9.83 & 662.86 & -91.86 \\
\hline Volgograd & Volgograd & $\begin{array}{l}48.49^{\circ} \mathrm{N} \\
43.43^{\circ} \mathrm{E}\end{array}$ & 145 & 403.00 & 8.4 & 701.45 & -289.46 \\
\hline
\end{tabular}

to the atmosphere by transpiration from vegetation and by direct evaporation. It is an important parameter that describes the soil water balance and affects soil formation. It has proven to be extremely difficult to measure PET directly but, fortunately, PET can be estimated from meteorological parameters such as temperature, radiation, wind velocity and humidity. The vapor flux and heat balance methods require meteorological data that are not or only partially available. On the other hand, Thornthwaite's PET empirical formula (Thornthwaite, 1948) can be used for any location at which precipitation and daily maximum and minimum temperature are recorded. It is based on the inherent assumption that a high correlation exists between mean temperature and some of the other pertinent parameters, such as radiation, atmospheric moisture and wind. This simple and universal applicability - rather than any claim to outstanding accuracy - has led to the widespread use of this method.

Thornthwaite's basic equation is given by:

$$
\mathrm{PET}=16(10 T / I)^{a}
$$

with:

PET $=$ monthly potential evapotranspiration $(\mathrm{mm})$;

$T=$ mean monthly temperature $\left({ }^{\circ} \mathrm{C}\right)$;

$I=$ a heat index for a given area which is the sum of 12 monthly index values $i$, whereby months with negative mean temperatures are excluded;

$i$ is derived from the mean monthly temperatures using the following formula:

$i=(T / 5)^{1.514}$;

$a=$ an empirically derived exponent, which is a function of $I$;

$a=6.7 \times 10^{-7} I^{3}-7.71 \times 10^{-5} I^{2}+1.79 \times 10^{-2} I+0.49$. A corrected value of PET that takes into account both the dependence of daylight time on the latitude and the variable month length is given by:

$$
\mathrm{PETc}=\operatorname{PET} \times(N / 12) \times(d / 30)
$$

with:

$N=$ Mean monthly values of daylight duration (in hours) at the location latitude; $d=$ days in the month

(Dunne and Leopold, 1978).

We used the following sources of climatic data to calculate PETc:

Argentina: Estadísticas Climatológicas 1971-1980 del Servicio Meteorológico Nacional (SMN), Comando de Regiones Aereas, Fuerza Aerea Argentina. Edited in Buenos Aires, 1986, SIN 0325-489;

Russia: INTERNET web page of the World Meteorological Organization, World Weather Information Service, Russian Federation Service for Hydrometeorology and Environmental Monitoring (ROSHYDROMET); http://www.worldweather.org/107/m107.htm;

China: Climatic statistic data based on month-annual values of the "tr055" directory contains 12 files (11 data files plus this documentation file) associated with data described in the DOE Technical Report, TR055, for the period 19711980. Climate Databases of the People's Republic of China, 1841-1988 (CDIAC); http://cdiac.ornl.gov/ftp/tr055/.

Monthly and annual (sum of the 12 monthly values) PETc were estimated from monthly climatic normal values for each location of Argentina, China and Russia. An annual precipitation surplus/deficit was computed by subtracting the annual PETc from annual TP; this was used as index of soil potential water storage (i.e. PWS $=\mathrm{TP} \times \mathrm{PETc}$ ).

\subsection{Discussion of the climatic analysis}

The climatic analysis is based on data obtained from meteorological stations closest to the sites where magnetic properties of the soils and paleosols were measured (few kilometers away from each site, and similar altitude). In Russia (magnetic data from Maher et al., 2003) climate records and magnetic measurements are available for the same sites. In Argentina, Zarate's closest meteorological station is San Pedro; and Veronica's closest meteorological station is in Punta Indio (Orgeira et al., 2006). Chinese Dujuanjiapo site (magnetic data from Bloemendal and Liu, 2005) has its closest meteorological station in Xian, and Luchuan has its closest meteorological station in Qinyiang (Table 2).

The Argentinean sites are characterized by a higher an- 


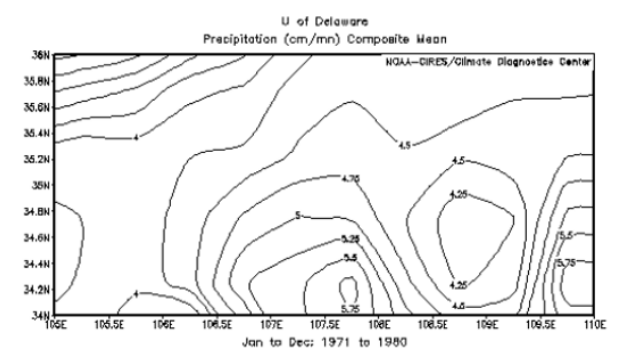

a
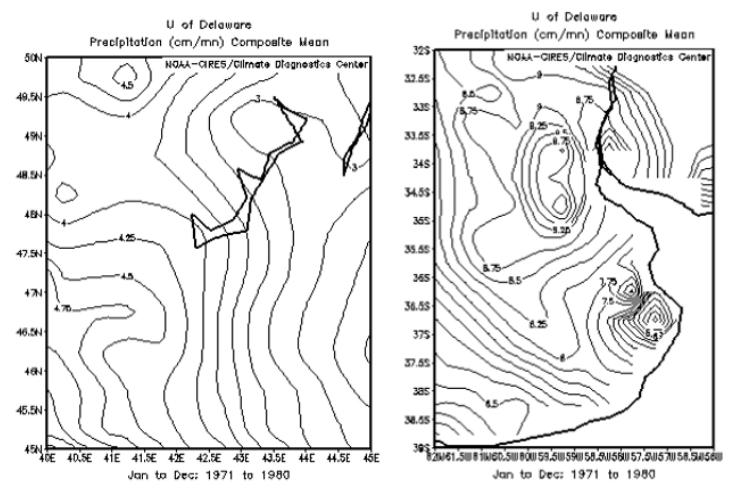

h

Fig. 4. TP distribution in the analized areas. UDel_AirT_Precip data provided by the NOAA-CIRES ESRL/PSD Climate Diagnostics branch, Boulder, Colorado, USA, from their Web site at http://www.cdc.noaa.gov/.
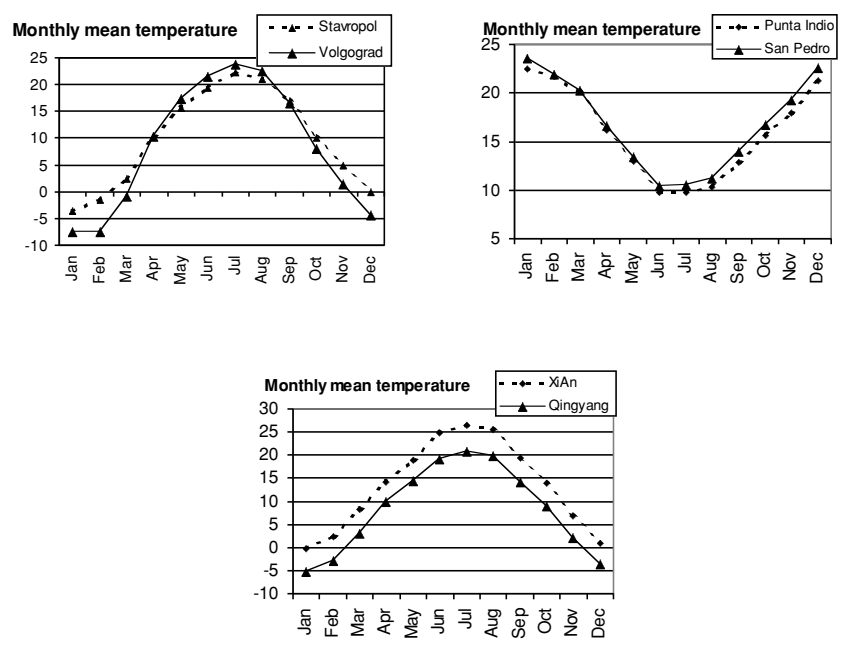

Fig. 5. Monthly mean temperature in the analized areas.

nual TP than that of all other sites by almost a factor of 2 (Table 2). The TP of these sites increases towards NE (Fig. 4(c)). In China, Xian is characterized by a lower annual TP than Quinyiang. This difference arise from an orographic effect due to the location of Xian in a depression (Fig. 4(a)). In Russia, the TP is characterized by a gradient that increases towards W (Fig. 4(b)).

It is evident that TP cannot explain the different magnetic properties of the San Pedro soils on one hand (enhancement), and Punta Indio soils on the other (depletion). Moreover, if one assumes Maher and Thompson's (1994, 1995) correlation between TP and magnetic enhancement,
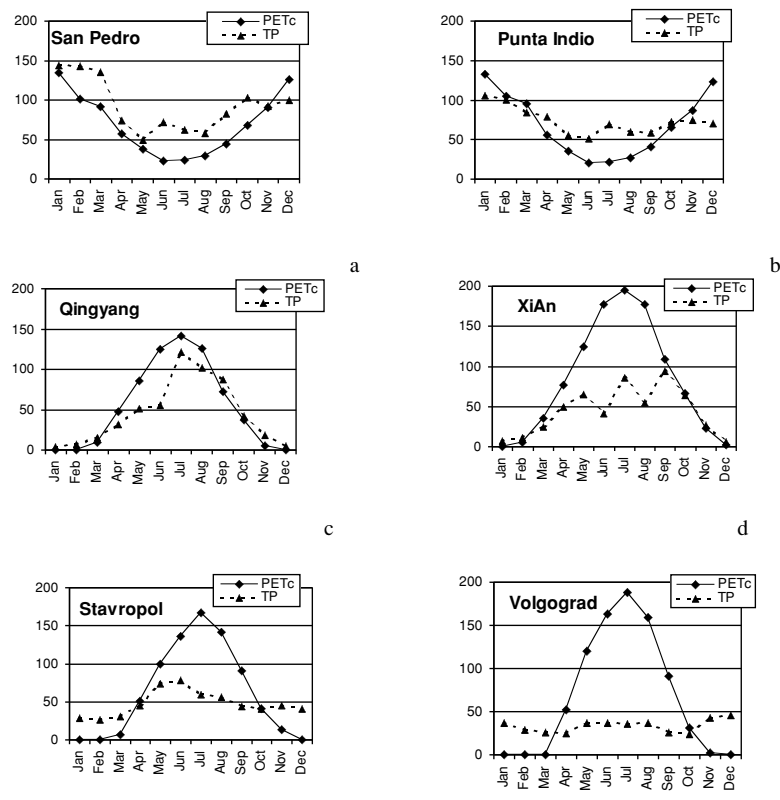

Fig. 6. PETc and TP for the analized areas.

the Chinese and Russian soils should be less magnetically enhanced that the Argentinean. These results show clearly that a global model for the soil magnetic properties cannot rely solely on the total annual precipitation.

On the other hand, Russian and Chinese sites have similar monthly temperatures, which are below freezing during winter. Temperatures in the Pampean plains are always above the freezing point, and higher on average than those of Russian and Chinese sites (Table 2, Fig. 5).

PETc values and PWS index were calculated for the selected areas (Argentina, China and Russia). They are show in Fig. 6 and Table 2.

San Pedro, Punta Indio (Pampean plain) and Volgograd (Russia) are characterized by similar high PETc values (Table 2). However, the magnetic properties of these three sites are quite different. As a consequence, this index seems not to be useful to explain magnetic behavior.

The potential water storage (PWS), defined as PWS = TP - PETc, can be used as a proxy for the water content of a soil, which is expected to have a great effect on the pedogenesis of magnetic minerals. PWS values show a clear and consistend differences between Argentina, China and Russia. Only Argentinian soils have a positive PWS, indicating a positive water balance in the soil (Table 2). On the other hand, Xian and Volgograd are characterized by the highest water deficit (PWS <0) (Table 2). Stavropol is characterized by the highest magnetic signal enhancement among the Russian sites (Maher et al., 2003).

Form these observations we conclude that, at a regional level, the PWS index is directly correlated with the magnetic signal. This correlation does however not hold for localities characterized by a positive PWS, such as the Argentinian sites. We therefore postulate the existence of a critical threshold, at PWS $=0$, above which reductive conditions prevent a magnetic enhancement.

The whole Pampean plain region is characterized by positive PWS values (Table 2) and a lack of magnetic en- 
hancement. The only exception was found in Zárate whose present soils are magnetically enhanced (Orgeira et al., 2006). Since Zárate is also the locality with the highest PWS, we hypothesize the existence of a second PWS threshold above which the formation of pedogenic minerals overcompensates the magnetization decrease related to dissolution processes occurring during part of the year. It is not yet clear if the magnetic enhancement observed in Zárate is transitional, or if it is a net result of the balance between chemical precipitation and dissolution over a long period. Furthermore, since the dissolution rate of magnetite is proportional to the surface area (Canfield and Berner, 1987), it is reasonable to expect the pedogenic magnetite to be completely destroyed every time the detrital minerals are dissolved. Further results are needed to outline the exact relationship between PWS and thepedogenesis of magnetic minerals.

Our tentative model for the pedogenesis of iron minerals imply a strongly nonlinear answer of the soil magnetic properties to changes in the climatic conditions. In this frame, PWS plays the role of a "switch" for the onset of a reductive dissolution of detrital magnetic minerals (PWS $>0$ ), and the precipitation of pedogenic iron oxides.

\section{Paleoclimate Implications of the Obtained Re- sults}

We will now interpret the magnetic signature of the soil sites discussed in Section 4, using the PWS as climate proxy, and the magnetic pedogenesis model discussed in Section 2.

Magnetically enhanced paleosols are found in sites characterized by a negative PWS (China and Russia). As long as PWS is negative, moderately/episodic reducing conditions during rainy periods lead to the generation of biogenic SP magnetite/maghemite. The correlation between TP and magnetic enhancement proposed by Maher and Thompson (1994) is valid for thoses soils.

The opposite trend is observed in soils and paleosols from Pampean sites (Argentina), where PWS is positive. The predominant magnetic signature of paleosols developed on loess and loessic sediments from this region is a decrease of the magnetic signal (Table 1). According to our pedogenic model, this is due to a net loss of ferrimagnetic minerals produced by the dissolution of detrital titanomagnetites associated to a positive PWS. A comparison with modern soils from the same area suggests that the paleosols formed in a climate whith PWS values similar to those measured at present in the central-eastern area of Buenos Aires (Orgeira et al., 2006). This paleoclimatic condition mainly dominated the area during the latest Pleistocene and the Holocene. However, the association of depletion of ferrimagnetic minerals with presence of high coercivity minerals at different times (Table 1) indicates periods with drier conditions than the present ones.

\section{Conclusions}

-Indexes of Potential water storage (PWS) were determined for different sites of Russia, China and Argentina. A comparison with magnetic data from the same sites suggests the existence of one or eventually two climatic thresholds.
-The first threshold is a PSW value above which the soil environment becomes seasonally reduced. The reducing conditions, combined with the presence of organic ligands, induce the partial dissolution of ferrimagnetic minerals (titanomagnetite and/or magnetite). This is the case for the analyzed present soils and paleosols of Argentina.

-The dissolution of detrital ferrimagnetic minerals is eventually reiforced by mechanism similar to the one discussed in Florindo et al. (2003) Acording to this model, the pore water silica generated from the diagenesis of silicic volcanic ash contained in Pampean loess favors the dissolution ferromagnetic minerals. In this case, iron mineral depletion is partially dependent on the nature of the source material.

-On the other hand, when PWS is negative, magnetic minerals are preserved in the soil. In addition, pedogenic iron oxides will form under moderately reductive conditions mainly by biological action. These are the case of the analyzed Russia present soils and China paleosols.

- A second threshold could be a PWS value constrained by the two Argentinean sites San Pedro (PWS = $291 \mathrm{~mm}$ ) and Punta Indio (PWS $=75 \mathrm{~mm}$ ). Above this threshold, a net positive balance exists between the precipitation and the dissolution of ferrimagnetic minerals.

Acknowledgments. We thanks Consejo Nacional de Investigaciones Científicas y Técnicas de Argentina (CONICET) and Universidad de Buenos Aires for financial support.

We want to thanks specially Dr. R. Egli and Dr. A. Fazio for their invaluable advices and corrections, and we also thanks the revision comments of an anonimous referee.

\section{References}

Ameghino, F., Contribución al conocimiento de los mamíferos fósiles de la República Argentina, Academia Nacional de Ciencias, VI, 1-1027, Córdoba, 1889.

Ameghino, F., Las formaciones sedimentarias de la región litoral de Mar del Plata y Chapadmalal, An. Museo Nac. Histor. Nat., 10, 343-428, 1908.

Appelo, C. A. J. and D. Postma, Geochestry, Groundwater and Pollution, Balkema, Rotterdam, 1993.

Banerjee, S. K. and C. Hunt, Separation of local signals from the regional paleomonsoon record of the Chinese loess plateau. A rock-magnetic approach, Geophy. Res. Lett., 20, 843-846, 1993.

Bloemendal, J. and X. Liu, Rock magnetism and geochemistry of two pliopleistocene Chinese loess-paleosols sequences- implications for quantitative paleoprecipitation reconstruction, Paleogeograph. Paleoclimatol. Paleoecol., 226, 149-166, 2005.

Canfield, D. E. and R. A. Berner, Dissolution and pyritization of magnetite in anoxic marine sediments, Geochim. Cosmochim. Acta, 51, 645-659, 1987.

Claperton, C., Quaternary Geology and Geomorphology of South America, Elsevier, Amsterdam, 1993.

Dunne, T. and L. B. Leopold, Water in Environmental Planning, W. H. Freeman and Co., San Francisco, 1978.

Evans, M. E. and F. Heller, Environmental Magnetism. Principles and Applications of Enviromagnetics, Academic press, Elsevier Science, Amsterdam, 2003.

Fang, X.-M., J.-J. Li, S. K. Banerjee, M. Jackson, E. Oches, and R. van der Voo, Millennial-scale climatic change during the last interglacial period: superparamagnetic sediment proxy from paleosol S1, western Chinese Loess Plateau, Geophys. Res. Lett., 26, 2485-2488, 1999.

Fidalgo, F., Provincia de Buenos Aires. Continental. CADINQUA, edited by M. Iriondo, El Holoceno en la Argentina, vol. 1, pp. 23-38, 1992.

Fidalgo, F., F. De Francesco, and R. Pascual, Geologia Superficial de la Llanura Bonaerense. In: Geologia de la Provincia de Buenos Aires, VI Congreso Geologico Argentino, Relatorio, Bahá Blanca, 103-138, 1975. 
Fidalgo, F., J. C. Riggi, R. O. Gentile, H. A. Correa, and N. Porro, Los "Sedimentos Postpampeanos" continentales en el ámbito sur bonaerense, Rev. Asoc. Geol. Argentina, 46, 239-256, 1991.

Florindo, F., A. P. Roberts, and M. R. Palmer, Mangetite dissolution in sili-ceous sediments, Geochem. Geophys. Geosystems, 4, 2003.

Freeze, R. A. and J. A. Cherry, Groundwater, Prentice-Hall, Englewood Cliffs, New Jersey, 1979.

Frenguelli, J., Observaciones geológicas en la región costanera Sur de la Provincia. de Buenos Aires, Univers. Nac. Litoral. Fac. Cienc. Educac., An. II, 1-145, 1928.

Frenguelli, J., El Platense y sus diatomeas. Museo de la Plata Rev. II (nueva ser.), Geol. 1 and 3 Paleontológica, 287-311 and 77-221, 1945.

Frenguelli, J., Rasgos generales de la morfología y geología de la provincia de Buenos Aires. Provincia de Buenos aires, Ministerio de Obras Públicas de la Provincia de Buenos Aires, Lab. Ensayos Materiales Invest. Tecnol. (LEMIT) Ser. II, 33, 1-72, 1950.

Frenguelli, J., Loess y limos pampeanos. Serie Técnica y didáctica No. 7 Ministerio de Educación de la Nación, Universidad Nacional de La Plata, Facultad de Ciencias Naturales y Museo de La Plata, 1955.

Frenguelli, J., Neozoico. En Geografía de la República Argentina II (3), 1-218, GAEA, Soc. Argentina Estud. Geográf, Buenos Aires, 1957.

Han, J., H. Lu, N. Wu, and Z. Guo, Magnetic susceptibility of modern soils in China and climate conditions, Stud. Geophys. Geodet., 40, 262-275, 1996.

Heller, F., X. Liu, T. S. Wu, and T. C. Xu, Magnetic susceptibility of loess in China, Earth Planet. Sci. Lett., 103, 301-310, 1991.

Heller, F., C. D. Shen, J. Beer, X. M. Liu, T. S. Liu, and A. Bronger, Quantitative estimates and paleoclimatic implications of pedogenic ferromagnetic mineral formation in Chinese loess, Earth Planet. Sci. Lett., 114, 385-390, 1993.

Liu, Q., S. Banerjee, M. J. Jackson, F. Chen, Y. Pan, and R. Zhu, Determining the climatic boundary between the Chinese loess and palaeosol: evidence from aeolian coarse-grained magnetite, Geophys. J. Int. Volcanol., 156, 267-274, 2004.

Liu, X., J. Shaw, T. Liu, F. Heller, and B. Yuan, Magnetic mineralogy of Chinese Loess and its significance, Quaternary Research, 42, 162-165, 1992.

Liu, X., T. Rolph, J. Bloemendal, J. Shaw, and T. S. Liu, Quantitative estimates of paleoprecipitation at Xinfeng, in the Loess Plateau of China, Paleogeograph. Paleoclimatol. Paleoecol., 13, 243-248, 1995.

MacBride, J., Environmental Chemistry of Soils, Oxford University Press, Oxford, 1994

Maher, B. A., Characterization of soils by mineral magnetic measurements, Phys. Earth Planet. Int., 42, 76-92, 1986.

Maher, B., Magnetic properties of modern soils and Quaternary loessic paleosols: paleoclimatic implications, Palaeogeogr. Palaeoclimatol. Palaeoecol., 137, 25-54, 1998.

Maher, B. and R. Taylor, Formation of ultrafine-grained magnetite in soils, Nature, 336, 368-379, 1988.

Maher, B. and R. Thompson, Mineral magnetic record of the Chinese loess and paleosols, Geology, 19, 3-6, 1991

Maher, B. and R. Thompson, Pedogenesis and paleoclimate. Interpretation of the magnetic susceptibility record of Chinese loess-paleosol sequences, Geology, 22, 857-859, 1994.

Maher, B. A. and R. Thompson, Paleorainfall reconstruction from pedogenic magnetic susceptibility variations in the Chinese loess and paleosols, Quat. Res., 44, 383-391, 1995.
Maher, B. A. and R. Thompson (eds.), Quaternary Climates, Environments and Magnetism, Cambridge University Press, Cambridge, 1999.

Maher, B. A., A. Alekseev, and T. Alekseeva, Magnetic mineralogy of soils across the Russian Steppe: climatic dependence of pedogenic magnetite formation, Palaeogeograph. Palaeoclimatol. Palaeocol., 201, 321-341, 2003.

Mullins, C. E., Magnetic susceptibility of the soil and its significance in soil sequence-a review, J. Soil Sci., 28, 223-246, 1977.

Nicolli, H. B., A. Tineo, J. W. García, C.M. Falcón, M. H. Merino, M. C. Etchechurry, M. S. Alonso, and O. R. Tófalo, The role of loess in groundwater at salí River Basin, Argentina, in Water-rock Interation, vol. 2, edited by R. W. Wanty and R. R. Seal II, 1591-1595, Balkema Publishers, Rotterdam, 2004.

Orgeira, M. J., A. M. Walther, C. A. Vásquez, I. Di Tommaso, S. Alonso, G. Sherwood, Yuang Hu, and J. F. A. Vilas, Mineral magnetic record of paleoclimate variation in loess and paleosol from the Buenos Aires formation (Buenos Aires, Argentina), J. South Am. Earth Sci., 11, 561$570,1998$.

Orgeira, M. J., A. M. Walther, R. Tófalo, C. A. Vásquez, T. Berquó, C. Favier Dubois, and H. Bhonel, Environmental magnetism in fluvial and loessic Holocene sediments and paleosols from the Chacopampean Plain (Argentina), J. South Am. Earth Sci., 16, 259-274, 2003.

Orgeira, M. J., F. X. Pereyra, C. Vásquez, E. Castañeda, and R. Compagnucci, Señal magnética en suelos actuales de la provincia de Buenos Aires, Argentina: su relación con el clima, Rev. Espan. Geo-Temas, 6, 311-314, 2004

Orgeira, M. J., F. X. Pereyra, C. Vásquez, E. Castañeda, and R. Compagnucci, Environmental magnetism in present soils, Buenos Aires province, Argentina, J. South Am. Earth Sci., 2006 (in press).

Parodi, L. J. and R. Parodi Bustos, Apuntes para la geología de la costa Atlántica de la provincia de Buenos Aires, con descripción de la Formación Malacara, An. Soc. Científ. Argentina, 153, 139-156, 1952.

Pascual, R., E. Ortega Hinojosa, D. Gordar, and E. Tonni, Las edades del Cenozoico mamalífero de la Argentina con especial atención a aquellos del territorio bonaerense, Provincia de Buenos Aires, Com. Invest. Científ. An., 6, 165-193, 1965.

Stumm, W., Chemestry of the solid-water interface. Processes at the mineral-water and particle-water interface in natural systems, WileyInterscience, John Wiley and Sons, New Yorkp, 1992.

Teruggi, M. E., The nature and origin of the Argentinian loess, J. Sediment. Petrol., 27, 322-332, 1957.

Thornthwaite, C. W., An approach toward a rational classification of climate, Geograph. Rev., 38, 55-94, 1948.

Vásquez, C. A., A. M. Walther, M. J. Orgeira, I. Di Tommaso, S. Alonso, and J. F. A. Vilas, Magnetic properties and environmental conditions: study of a paleosol of Chacopampean plain (Argentina), Quat. South Am. Antarctic Peninsula, 11, 195-206, 1998.

Walther, A. M., M. J. Orgeira, and H. F. Lippai, Magnetismo de rocas en sedimentos cenozoicos tardíos en San Antonio de Areco provincia de Buenos Aires, Rev. Asoc. Geolog. Argentina, 59, 433-442, 2004.

Zhou, L. P., F. Oldfield, A. G. Whintle, S. G. Robinson, and J. T. Wang, Partly pedogenic origin of magnetic variations in Chinese loess, Nature, 346, 737-739, 1990.

M. J. Orgeira (e-mail: orgeira@gl.fcen.uba.ar) and R. H. Compagnucci 